\title{
ПРОБЛЕМА СТАДИЙ СОВЕРШЕНИЯ ПРЕСТУПЛЕНИЯ В НАУЧНОМ ТВОРЧЕСТВЕ Н.Ф. КУЗНЕЦОВОЙ И ЕЁ ДАЛЬНЕЙШЕЕ РАЗРЕШЕНИЕ
}

\begin{abstract}
Аннотация: В статье отмечаются научные достижения Н.Ф. Кузнецуовой по разрешению проблемы стадий совершения преступления, их соотношению с неоконченными преступлениями. Показано значение этих достижений для разработки в последующем учения о стадиях осуществления преступного намерения: новой парадигмы в мировой уголовно-правовой науке.

Автором установлена интеллектуальная связь между понятиями «стадии осуществления преступного намерения» («стадия подготовки к исполнению преступления» и «стадия исполнения преступления»)» и, в частности, понятиями «нападение», «посягательство», которые ранее считались не связанными.

Излагаются основные положения этого учения и разработанные на его основе законодательные новелльл. Ставится вопрос о скорейшем внедрении этого учения и законодательных новелл, разработанных на его основе, в учебный проиесс и уголовное законодательство.

Ключевые слова: Н.Ф. Кузнецова, научные достижения, стадии совершения преступления, преступления по степени их завершённости, соотношение стадий совершения преступления и преступлений по степени их завершённости; преступления, совершаемые с прямым умыслом; учение о стадиях осуществления преступного намерения: новая парадигма в мировой уголовно-правовой науке; стадия подготовки к исполнению преступления, стадия исполнения преступления; нападение, посягательство, попытка; совокупность научных и законодательных новелл.
\end{abstract}

Мы как карлики на плечах гигантов, и потому можем видеть больше и дальше, чем они Бернар Шартский, а за ним - Исаак Ньютон

В науке генералов нет и истина не устанавливается голосованием Марк Игоревич Бажанов

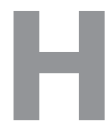

еобходимость написания настоящей статьи, её сюжет были вызваны и обусловлены двумя важными обстоятельствами.

Первое. Необходимостью отдать должное выдающимся научным достижениям Нинели Фёдоровны Кузнецовой: в своё время в разрешение так называемой ранее проблемы стадий совершения преступления тогда ещё начинающий исследователь внесла важный вклад.

Н.Ф. Кузнецова впервые в истории уголовно-правовой науки вскрыла и в общих чертах решила проблему соотношения стадий совершения преступления и неоконченного преступления, оконченного преступления. При этом автор, обоснованно отмечала, что стадии совершения преступления - это доктринальное понятие, неоконченное и оконченное преступления - законодательные установления.

Забегая вперёд, необходимо отметить, что, конечно, в те далёкие пятидесятые годы прошлого столетия Н.Ф. Кузнецова совсем не представляла себе, что стоит по существу у истоков учения о стадиях осуществления преступного намерения: новой парадигмы в мировой уголовно-правовой науки. Это учение, появившееся как таковое спустя чуть менее пятидесяти лет, открыло нам, как оказалось, состав (структуру) преступного деяния, совершаемого с прямым умыслом, явилось системообразующим основанием для научно обоснованного законодательного 


\section{Право и политика $3(159) \cdot 2013$}

конструирования и правильного правоприменения ответственности за преступления по степени их завершённости, преступлений, совершаемых с прямым умыслом, правового регулирования необходимой обороны.

Второе. В последнее время всё настойчивее раздаются, и, надо сказать, небезосновательно, предложения о принятии нового УК РФ либо, по крайней мере, о принятии его новой редакции. И в связи с этим встаёт вопрос: как скоро и что нового, прогрессивного будет заложено в нём по проблеме ответственности за преступления, совершаемые с прямым умыслом?

Но обо всём по порядку.

1. Проблема стадий совершения преступления в научном творчестве Н.Ф. Кузнецовой.

Так сложилось, что свой путь в науку Нинель Фёдоровна Кузнецова начала с исследования названной проблемы: сложной и имеющей большое значение для науки, законодательства и практики его применения.

Профессор П.С. Яни, кстати, ученик Н.Ф. Кузнецовой, пишет: «Профессор Н.Ф. Кузнецова долгие годы борется за отражение в законе более точного определения неоконченного преступления. Говоря о новаторстве в своей научной деятельности, она вспоминает, как ещё в начале 50-х годов аспиранткой первого года обучения на студенческом научном кружке, которым руководил профессор А.Н. Трайнин, ею были высказаны положения, которые расходились с общепринятыми. «Я доказывала, - продолжает она разговор, - что обнаружение умысла - не стадия преступления, что стадии не являются синонимами неоконченного прерванного преступления в виде приготовления к преступлению и покушения на преступление, что невозможен добровольный отказ от покушения, которое всегда уже прервано по не зависящим от лица обстоятельствам, что в понятие приготовления необходимо включить такой обязательный признак, как прерванность до начала исполнения состава по не зависящим от лица обстоятельствам, что характеристика добровольного отказа должна быть иной, нежели в действующем УК. Эти идеи потом защищались в кандидатской диссертации (Ответственность за приготовление и покушение по советскому уголовному праву. М., 1953. - М.Р.) и вошли в книгу «Ответственность за приготовление к преступлению и покушение на преступление» (1958). Прошло всего лишь четыре десятилетия, - иронично добавляет Нинель Фёдоровна, и в УК 1996 г. глава 6 Кодекса «Неоконченное преступление» эти предложения реализовала» ${ }^{1}$.

Следует сказать, что к тому времени в науке уголовного права уже несколько столетий безраздельно господствовало положение о том, что преступление совершается в

\footnotetext{
${ }^{1}$ Цит. по: Яни П.С. О личности учёного // Весь мир живёт до тех пор, пока живёт память человека / Под общей редакцией профессора В.С. Комиссарова. М., 2006. С. 161-162.
}

три стадии: 1) приготовление; 2) покушение; 3) оконченное преступление. Но Н.Ф. Кузнецова (пожалуй, единственная из исследователей) заняла, по нашему мнению, принципиально правильную позицию относительно различения, по ее выражению, стадий развития преступной деятельности и видов неоконченного преступления. Под стадиями она понимала приготовительные действия и исполнение преступления, под видами неоконченного преступления - приготовление к преступлению и покушение на преступление 2 . Однако впоследствии Н.Ф. Кузнецова к двум указанным ею стадиям развития преступной деятельности необоснованно, по нашему мнению, присовокупила третью - наступление преступных последствий ${ }^{3}$.

Но это было, как оказалось во второй половине последнего десятилетия ушедшего века, только началом большого пути, имя которому - учение о стадиях осуществления преступного намерения. Но об этом чуть ниже.

2. Дальнейшее разрешение проблемы стадий совершения преступления.

Своё дальнейшее развитие идеи Н.Ф. Кузнецовой получили в работах выдающегося советского учёного Н.Д. Дурманова $^{4}$, А.П. Козлова ${ }^{5}$, автора этих строк ${ }^{6}$, многочисленной плеяды других советских и российских учёных.

В результате творческого развития взглядов, в частности, Н.Ф. Кузнецовой на анализируемую проблему, автором этих строк, с опорой на философские идеи Аристотеля, диалектический метод познания преступлений, совершаемых с прямым умыслом, были разработаны основные положения учения о стадиях осуществления преступного намерения и видах преступлений по степени их завершённости, концепция совершенствования законодательства об уголовной ответственности за преступления по степени их завершённости.

\footnotetext{
${ }^{2}$ Кузнецова Н.Ф. Ответственность за приготовление к преступлению и покушение на преступление по советскому уголовному праву. М., 1958. С. 39-41.

${ }^{3}$ Советское уголовное право. Общая часть: Учебник / Под ред. Г.А. Кригера, Н.Ф. Кузнецовой, Ю.М. Ткачевского. 2-е изд., доп. и перераб. М., 1988. С. 164; Уголовное право. Общая часть / Под ред. Н.Ф. Кузнецовой и др. М., 1993. С. 176; Учебник уголовного права. Общая часть. М., 1996. С. 164.

${ }^{4}$ См: Дурманов Н.Д. Стадии совершения преступления по советскому уголовному праву. М., 1955.

${ }^{5}$ См.: Козлов А.П.: 1) Стадии и неоконченное преступление. Вып. 1. Стадии совершения преступления: Учеб. пособие / Краснояр. гос. ун-т. Красноярск, 1993; 2) Неоконченное преступление: Учеб. Пособие / Краснояр. гос. ун-т. Красноярск, 1999.

${ }^{6}$ См.: Редин М.П.: 1) Понятия оконченного и неоконченного преступлений в уголовном законодательстве Российской Федерации // Правоведение. 1997. № 1. С. 111-121; Осуществление преступного намерения и неоконченное преступление // Вестник Саратовской государственной академии права. 1998. № 2. С. 37-45; 2) Осуществление преступного намерения и неоконченное преступление // Правоведение. 1999. № 1. С. 159-168.
} 
На основе этого учения решена проблема соотношения стадий осуществления преступного намерения и преступлений по степени их завершённости, добровольного отказа от доведения до конца деятельности по реализации преступления ${ }^{7}$.

В основе эффективного законодательного регулирования ответственности за преступления по степени их завершенности и вообще за преступления, совершаемые с прямым умыслом, нормативных условий добровольного отказа от преступления, и их правильного правоприменения, должно лежать учение о стадиях осуществления преступного намерения ${ }^{8}$.

Именно оно, и образующиеся на стадиях осуществления преступного намерения (стадии подготовки к исполнению преступления и стадии исполнения преступления) преступления по степени их завершенности (приготовление к исполнению преступления, покушение на исполнение преступления, оконченное преступление), добровольный отказ от доведения до конца деятельности по реализации преступления, представляют собой некую целостную систему.

Только эта система позволяет раскрыть содержательную сторону таких преступлений и добровольного отказа от доведения до конца деятельности по реализации преступления.

Отсутствие в уголовно-правовой доктрине учения о стадиях осуществления преступного намерения вполне закономерно привело к отсутствию последовательности, системности, научной обоснованности в законодательном регулировании ответственности за названные виды преступлений, в нормативных условиях добровольного отказа от доведения до конца деятельности по реализации преступления, и в их правоприменении.

Мы использовали системный подход к исследованию преступлений по степени завершенности и их наказуемости, добровольного отказа от доведения до конца деятельности по реализации преступления. Применили диалектические методы (в т. ч. генетический метод) познания преступлений, совершаемых с прямым умыслом9.

\footnotetext{
${ }^{7}$ См.: Редин М.П.: 1) О соотношении стадий осуществления преступного намерения и видов преступлений по степени их завершенности, добровольного отказа от доведения до конца деятельности по реализации преступления [Электронный ресурс] // Режим доступа: http://sartraccc.sgap.ru/i.php?oper=read_file\&filename $=\mathrm{Pub} /$ redin(02-10-08). htm; 2) О соотношении стадий осуществления преступного намерения и видов преступлений по степени их завершенности // Вестник Орловского государственного университета. Серия: «Новые гуманитарные исследования». 2008. № 4. С. 77-85.

${ }^{8}$ Подробно см.: Редин М.П. Преступления по степени их завершённости. Монография. - М.: Издательство «Юрлитинформ», 2006.; др. многочисленные опубликованные работы автора по этой тематике.

${ }^{9}$ Редин М.П. О методологии и методах научного познания преступлений, совершаемых с прямым умыслом // Юридическая мысль (г. Санкт-Петербург). 2006. № 6. С. 48-55.
}

Это дало возможность разработать основные положения учения о стадиях осуществления преступного намерения, исходные положения концепции совершенствования законодательства об ответственности за преступления по степени их завершенности, авторский проект главы 6 «Преступления по степени завершенности и их наказуемость» Уголовного кодекса Российской Федерации ${ }^{10}$.

Таким образом, виды преступлений по степени их завершенности (приготовление к исполнению преступления, покушение на исполнение преступления, оконченное преступление) и добровольный отказ от доведения до конца деятельности по реализации преступления образуются при указанных в законе обстоятельствах в процессе осуществления лицом преступного намерения.

А именно. Приготовление к исполнению преступления образуется по не зависящим от лица обстоятельствам на стадии подготовки к исполнению преступления.

Покушение на исполнение преступления образуется по не зависящим от лица обстоятельствам на стадии исполнения преступления.

Оконченное преступление образуется на стадии исполнения преступления.

Добровольный отказ от доведения до конца деятельности по реализации преступления образуется по собственной воле лица, при осознании им возможности доведения таковой до конца, на стадии подготовки к исполнению преступления либо на стадии исполнения преступления.

Необходимо отметить, что в методологическом плане важность научно обоснованного исследования рассматриваемой темы выходит далеко за еепределы. Поскольку учение о стадиях осуществления преступного намерения является системообразующим основанием для законодательного конструирования и правильного правоприменения всех без исключения преступлений, совершаемых с прямым умыслом ${ }^{11}$, необходимой

${ }^{10}$ См.: Редин М.П. Преступления по степени их завершенности. C. 27-28, 188-197.

${ }^{11}$ См., напр.: Редин М.П. О состоянии и перспективах использования в уголовном законотворчестве и правоприменении учения о стадиях осуществления преступного намерения // Изменение преступности и актуальные вопросы законодательства по борьбе с ней / Материалы Междунар. науч.-практ. конф., состоявшейся в Тамбовском филиале Московского университета МВД России, 23-24 июня 2005 г. - Тамбов: Тамбовский филиал МосУ МВД России, 2005. С. 122-125; Он же. Учение о стадиях осуществления преступного намерения: его сущность, использование в законотворчестве и правоприменении // Материалы I Всероссийского конгресса по уголовному праву, посвященного 10-летию Уголовного кодекса Российской Федерации. М., 2006. С. 501-506; Он же. Еще раз об учении о стадиях осуществления преступного намерения // Современное право. 2007. № 5. С. 56-58; Он же. О конструкции составов преступлений, предусмотренных статьями 277, 295, 317 УК РФ // Следователь. 1999. № 2. С. 30-32; Еще раз о конструкции составов преступлений, предусмотренных статьями 277, 295, 317 УК РФ // Современное право. 2007. № 8. С. 86-91; Он же. О понятии посягательства на жизнь и конструкции составов преступлений, предусмотренных статьями 277, 295, 317 Уголовного 


\section{Право и политика $3(159) \cdot 2013$}

обороны ${ }^{12}$. Ведь понятия «нападение», «посягательство», «попытка» лежат в русле этого учения, поскольку являются вехами на пути осуществления преступного намерения.

Указанные исследования привели нас к следующим научным и законодательным новеллам.

1. Как это не удивительно, но до начала текущего века люди не представляли себе структуру деятельности лица по реализации преступного намерения - преступления, совершаемого с прямым умыслом - первой из двух основных категорий уголовного права.

Поэтому нам представляется, что важность учения о стадиях осуществления преступного намерения для науки уголовного права и законодательства равнозначна открытию спектрального анализа в физике, основанного на свойстве света разлагаться на составляющие его цветовые лучи, т.е. в спектр.

2. Стадии осуществления преступного намерения - это определенные этапы умышленной преступной деятельности лица, заключающиеся в подготовке к исполнению преступления и в исполнении задуманного этим лицом преступления. Таких стадий две: 1) стадия подготовки к исполнению преступления и 2) стадия исполнения преступления.

3. Подготовка к исполнению преступления - это такая стадия осуществления преступного намерения, в результате которой лицо нападает на объект преступления с целью причинения ему общественно опасного последствия.

4. Нападение лица на объект преступления с целью причинения ему общественно опасного вреда - это такая деятельность лица по реализации преступного намерения, при помощи которой должны быть осуществлены действия (бездействие), непосредственно направленные на исполнение преступления, т. е. - это оконченная подготовка к исполнению преступления.

5. Исполнение преступления - это такая стадия осуществления преступного намерения, в процессе которой лицо совершает умышленные действия (бездействие),

кодекса Российской Федерации // Безопасность бизнеса. 2007. № 3. С. 35-39; Он же. О квалификации бандитизма и преступных деяний, совершенных бандой // Современная организованная преступность и коррупция в России: состояние, тенденции, проблемы и возможности эффективного противодействия: тезисы Международной научнопрактической конференции (27-28 февраля 2007 года, г. Саратов): в 2 ч. / отв. ред. А.И. Демидов. Саратов: Изд-во ГОУ ВПО «Саратовская государственная академия права», 2007. Ч. 1. С. 232-237; Он же. Разбой (понятие, конструкция состава) // Современное право. 2007. № 10. С. 96-104; Он же. О понятии убийства в российском уголовном законодательстве // Российская юстиция. 2007. № 10. С. 48-49; Он же. Об ограничении законодательной регламентации смертной казни // Уголовное право: стратегия развития в XXI веке: материалы Пятой Международной научно-практической конференции 24-25 января 2008 г. - М., 2008. C. 224-228.

12 Редин М.П. О конструкции состава необходимой обороны (статья 37 Уголовного кодекса РФ) // Современное право. 2006. № 2. c. 47-53. непосредственно направленные на исполнение преступления (первая фаза) и непосредственно приводит преднамеренное в исполнение (вторая фаза).6. Посягательство лица на объект преступления с целью причинения ему общественно опасного последствия - это такая деятельность лица по реализации преступного намерения, при помощи которой преднамеренное должно быть непосредственно приведено в исполнение.

7. Преступление признается неоконченным, если в деятельности лица по реализации преступного намерения содержатся все признаки состава приготовления к исполнению преступления либо неполного или полного покушения на исполнение преступления, предусмотренного Особенной частью УК РФ.

8. Видами неоконченного преступления являются: приготовление к исполнению преступления, неполное покушение на исполнение преступления, полное покушение на исполнение преступления.

9. Приготовлением к исполнению преступления признаются приискание, изготовление или приспособление лицом средств или орудий исполнения преступления, приискание соучастников преступления, сговор на исполнение преступления либо иное умышленное создание условий для исполнения преступления, не доведенное до начала исполнения преступления по не зависящим от этого лица обстоятельствам.

10. Приготовлению к исполнению преступления как виду неоконченного преступления по объективной стороне присущи, по нашему мнению, следующие признаки:

1) подготовительные к исполнению преступления действия (бездействие) лица создают условия для исполнения этим лицом тяжкого либо особо тяжкого преступления. Мы полагаем, что выражение «подготовительные к исполнению преступления действия (бездействие)» является правильным, так как предполагает их осуществление на стадии подготовки к исполнению преступления. Выражение «приготовительные к исполнению преступления действия (бездействие)» непременно отождествляется с видом неоконченного преступления - приготовлением к исполнению преступления;

2) подготовительные к исполнению преступления действия (бездействие) лица являются общественно опасными, так как создают возможность для причинения общественно опасного вреда охраняемому уголовным законом объекту на стадии исполнения преступления;

3) подготовительные к исполнению преступления действия (бездействие) лица не входят в число обязательных признаков объективной стороны состава задуманного лицом определённого вида преступления, предусмотренного Особенной частью Уголовного кодекса;

4) подготовительные к исполнению преступления действия (бездействие) лица во времени предшествуют действиям (бездействию) по исполнению преступления; 
5) подготовительные к исполнению преступления действия (бездействие) лица всегда отделены во времени от действий (бездействия) по исполнению преступления;

6) подготовительные к исполнению преступления действия (бездействие) лица, в отличие от действий (бездействия) по исполнению преступления, зачастую отдалены в пространстве от конкретного охраняемого уголовным законом объекта преступления;

7) подготовительные к исполнению преступления действия (бездействие) лица сами по себе еще не создают непосредственной угрозы причинения общественно опасного вреда охраняемому уголовным законом объекту. Она возникает в результате дальнейших общественно опасных действий (бездействия) этого лица по осуществлению преступного намерения на стадии исполнения преступления;

8) в результате подготовительных к исполнению преступления действий (бездействия) лица создается нападение на охраняемый уголовным законом объект с целью причинения ему общественно опасного вреда;

9) подготовительные к исполнению преступления действия (бездействие) не доводятся лицом, причем окончательно, до начала исполнения преступления;

10) подготовительные к исполнению преступления действия (бездействие) не доводятся лицом до начала исполнения преступления всегда и только по не зависящим от этого лица обстоятельствам. Обстоятельства могут быть самыми различными, но не должны быть связаны с добровольным отказом этого лица от доведения до конца деятельности по реализации преступления.

11. Приготовлению к исполнению преступления как виду неоконченного преступления по субъективной стороне присущи, по нашему мнению, следующие признаки

1) наличие у лица прямого умысла на совершение подготовительных к исполнению преступления действий (бездействия) с целью последующего (на стадии исполнения преступления) осуществления определённого вида преступления: лицо осознает, что выполняемые им действия (бездействие) создают условия для исполнения конкретного преступления, и желает совершить эти действия (бездействие)

2) наличие у лица при совершении подготовительных к исполнению преступления действий (бездействии) ближайшей цели - создание возможности для причинения общественно опасного вреда охраняемому уголовным законом объекту, и конечной цели - совершение в последующем (на стадии исполнения преступления) определённого вида преступления, предусмотренного Особенной частью Уголовного кодекса, с прямым умыслом.

12. Покушению на исполнение преступления как виду неоконченного преступления по объективной стороне присущи, по нашему мнению, следующие признаки:

1) действиям (бездействию), непосредственно направленным на исполнение преступления, во времени предшествуют умышленные действия (бездействие) по созданию условий для исполнения преступления;

2) действия (бездействие), непосредственно направленные на исполнение преступления, предпринимаются лицом для безотлагательного выполнения оконченного преступления;

3) действия (бездействие), непосредственно направленные на исполнение преступления, с одной стороны, входят во вторую стадию осуществления преступного намерения - стадию исполнения преступления, с другой - не тождественны ей и включаются в самостоятельный состав неоконченного преступления - покушение на исполнение преступления.

Ведь для объективной стороны оконченного преступления характерно наличие действий (бездействия), вызвавших наступление задуманного лицом общественно опасного вреда, а для покушения на преступление - действий (бездействия), не вызвавших такового;

4) действия (бездействие) лица, непосредственно направленные на исполнение преступления, являются общественно опасными, так как создают посягательство на объект преступления, либо представляют собой непосредственное приведение преднамеренного в исполнение в целях причинения объекту преступления общественно опасного вреда, либо такой вред ему частично причиняют;

5) действия (бездействие), непосредственно направленные на исполнение преступления, не доводятся до конца преступления всегда и только по не зависящим от лица обстоятельствам. Обстоятельства могут быть самыми различными, но не должны быть связаны с добровольным отказом лица от доведения до конца деятельности по реализации преступления;

6) действия (бездействие), непосредственно направленные на исполнение преступления, выполняются лицом не полностью, либо не влекут за собой наступления общественно опасного вреда, предусмотренного статьей Особенной части Уголовного кодекса;

7) покушение на исполнение преступления охватывает не только действия (бездействие) лица, непосредственно направленные на исполнение преступления, но и предшествовавшие им умышленные действия (бездействие) этого лица по созданию условий для исполнения преступления.

13. Покушению на исполнение преступления как виду неоконченного преступления по субъективной стороне присущи, по нашему мнению, следующие признаки:

1) наличие у лица прямого умысла на исполнение преступления, задуманного им: лицо осознает, что его действия (бездействие) непосредственно направлены на исполнение определённого вида преступления, предусмотренного Особенной частью Уголовного кодекса, их общественную опасность, и желает выполнить указанные действия (бездействие) и довести преступление до конца. Если же лицо совершает «материальное» преступление, то 


\section{Право и политика 3 (159) • 2013}

содержанием его умысла охватывается также предвидение возможности или неизбежности наступления общественно опасного вреда и желание его наступления;

2) наличие у лица конечной цели - выполнение всех умышленных действий (бездействия), непосредственно направленных на исполнение преступления, и доведение преступления до конца.

14. Покушением на исполнение преступления признается нападение ${ }^{13}$ лица на объект преступления с целью причинения ему общественно опасного вреда, сопряженное с его умышленными действиями (бездействием), непосредственно направленными на исполнение преступления, если при этом преступление не было доведено до конца по не зависящим от этого лица обстоятельствам.

15. Неполным покушением на исполнение преступления признается нападение лица на объект преступления с целью причинения ему общественно опасного последствия, сопряженное с умышленными действиями (бездействием), непосредственно направленными на исполнение преступления, если при этом преступление не было доведено до непосредственного приведения преднамеренного в исполнение по не зависящим от этого лица обстоятельствам.

16. Полным покушением на исполнение преступления признается посягательство лица на объект преступления с целью причинения ему общественно опасного последствия, сопряженное с непосредственным приведением преднамеренного в исполнение, если при этом преступление не было доведено до конца по не зависящим от этого лица обстоятельствам.

17. Видами преступлений по степени их завершенности являются: приготовление к исполнению преступления, неполное покушение на исполнение преступления, полное покушение на исполнение преступления, оконченное преступление.

18. Преступление признается оконченным, если в деянии, совершённом лицом с прямым умыслом, содержатся все признаки состава определенного вида преступления, предусмотренного Особенной частью УК РФ.

19. Добровольным отказом от доведения до конца деятельности по реализации преступления признается окончательное и по собственной воле лица прекращение подготовки к исполнению преступления либо прекращение исполнения преступления, если это лицо осознавало возможность доведения до конца такой деятельности.

20. Общественная опасность неоконченного преступления всегда ниже, чем оконченного преступления.

Однако действующая система наказуемости неоконченного преступления (приготовления к исполнению преступления и покушения на исполнение преступле-

\footnotetext{
${ }^{13} \mathrm{O}$ нашем понимании понятия «нападение» см. Редин М.П. Пре-
} ступления по степени их завершенности. С. 24-28. ния), предусматривающая обязательное снижение срока или размера наказания только максимального срока или размера наиболее строгого вида наказания, предусмотренного статьей Особенной части УК РФ за оконченное преступление, не только не обеспечивает реализацию принципа справедливости в уголовном праве, но и нарушает конституционный принцип равенства граждан перед законом.

Нарушение принципа равенства граждан перед законом мы усматриваем во введении законодателем ч.ч. 2, 3 ст. 66 УК РФ без соответствующего снижения максимального срока или размера всех видов наказания (а не только наиболее строгого) и без соответствующего снижения минимального срока или размера всякого вида наказания, предусмотренного Особенной частью УК РФ за оконченное преступление (т.е. законодателем нарушен единыци, равный, адекватный социальным реалиям масштаб пенализации в уголовном законодательстве). Поэтому представляется необходимым установить за приготовление к исполнению преступления, неполное покушение на исполнение преступления, полное покушение на исполнение преступления действительно редуцированное наказание.

21. В гл. 6 УК РФ «Преступления по степени завершенности и их наказуемость» следует включить предлагаемую автором новую ст. $30^{2}$ «Наказуемость неоконченного преступления», а из ст. 66 «Назначение наказания за неоконченное преступление» гл. 10 УК РФ подлежат исключению ч.ч. 2, 3:

a) срок или размер наказания за приготовление к исполнению преступления не может превышать четверти санкции, предусмотренной соответствующей статьей Особенной части УК РФ за оконченное преступление;

б) срок или размер наказания за неполное покушение на исполнение преступления не может превышать половины санкции, предусмотренной соответствующей статьей Особенной части УК РФ за оконченное преступление;

в) срок или размер наказания за полное покушение на исполнение преступления не может превышать трех четвертей санкции, предусмотренной соответствующей статьей Особенной части УК РФ за оконченное преступление;

г) если четверть, половина, три четверти (ч.ч. 1-3 настоящей статьи) низшего предела санкции ниже минимального срока или размера, установленного для соответствующего наказания в статье Общей части настоящего Кодекса, назначается более мягкий вид наказания, чем предусмотрен соответствующей статьей Особенной части настоящего Кодекса за оконченное преступление.

22. Неоконченные преступления по своей тяжести должны относиться к самостоятельным категориям преступлений (в соответствии с их пониженными санкциями) со всеми вытекающими отсюда более мягкими иными уголовно-правовыми последствиями за их совершение. 
23. В ч. 1, 2 ст. 37 УК РФ признаки «посягательство, сопряженное с насилием, опасным для жизни обороняющегося или другого лица, либо с непосредственной угрозой применения такого насилия» и «посягательство, не сопряженное с насилием, опасным для жизни обороняющегося или другого лица, либо с непосредственной угрозой применения такого насилия», необходимо заменить соответственно на признаки «посягательство, соединенное с насилием, опасным для жизни обороняющегося или другого лица, либо с непосредственной угрозой применения такого насилия» и «посягательство, не соединенное с насилием, опасным для жизни обороняющегося или другого лица, либо с непосредственной угрозой применения такого насилия».

Необходимо изменить ч. 2.1 ст. 37 УК РФ, сформулировав ее так: «Не являются превышением пределов необходимой обороны действия обороняющегося лица, если это лицо вследствие неожиданности посягательства не могло объективно оценить его характер и опасность».

Необходимо внести соответствующие изменения в постановление Пленума Верховного Суда РФ от 27 января 2012 г. № 19 «О применении судами законодательства о необходимой обороне и причинении вреда при задержании лица, совершившего преступление».

24. Конструкция состава преступления, предусмотренного ч. 1 ст. 162 УК РФ должна быть сформулирована следующим образом: «Разбой, то есть нападение в целях хищения чужого имущества, соединенное с насилием, опасным для жизни или здоровья, либо с угрозой применения такого насилия».

Как мы полагаем, аналогичное содержание термин «нападение» должен иметь и в других составах преступлений Особенной части Уголовного кодекса Российской Федерации. Кроме статей 162, 209, это еще статьи 227 и 360 УК РФ.

25. Действующую законодательную конструкцию составов преступлений, предусмотренных статьями 277, 295, 317 УК РФ, по объективной стороне нельзя признать должной.

Необходимо сконструировать рассматриваемые составы преступлений аналогично составу разбоя, т. е. сконструировать их таким образом, чтобы они состояли из основных (посягательство на жизнь) и квалифицированных составов. В квалифицированные составы преступлений включить посягательство на жизнь, сопряжённое с причинением смерти соответствующим лицам.

Реализация этого предложения, мы надеемся, обеспечит должную дифференциацию уголовной ответственности и позволит более точно квалифицировать фактически содеянное, а также обеспечит назначение справедливого наказания за совершение названных преступлений.

Правильным, на наш взгляд, является понимание посягательства как всякой деятельности, при помощи которой преднамеренное должно быть непосредственно приведено в исполнение ${ }^{14}$.

Мы полагаем, что именно эти законодательные новеллы, теоретической основой которых является учение о стадиях осуществления преступного намерения: новая парадигма в мировой уголовно-правовой науке ${ }^{15}$, должны быть положены в основу нового УК РФ либо его новой редакции.

Безусловно, и мы это чётко осознаём, что разработанное учение требует дальнейшего совершенствования, развития и детализации, активного внедрения в учебный процесс, законодательство и практику его применения.

«Это время, когда наука, законодательство и судебная практика пойдут у нас рука об руку, можно надеяться, настанет скоро...», - считал, как оказалось, ошибочно, ещё в 1865 году великий русский юрист и учёный А.Ф. Кони. Вопреки этим надеждам, это время у нас настанет не скоро. И практика это наше предположение, к сожалению, подтверждает.

Потребовалось почти полвека для реализации первых законодательных предложений Н.Ф. Кузнецовой по проблеме правового регулирования оконченного и неоконченного преступлений.

Интересно, а какой срок потребуется для реализации теперь уже сегодня очевидных наших законодательных новелл по проблеме правового регулирования ответственности за преступления, совершаемые с прямым умыслом, правового регулирования необходимой обороны?

\section{Библиография:}

1. Дурманов Н.Д. Стадии совершения преступления по советскому уголовному праву. М., 1955.

2. Козлов А.П. Неоконченное преступление: Учеб. Пособие / Краснояр. гос. ун-т. Красноярск, 1999.

3. Козлов А.П. Стадии и неоконченное преступление. Вып. 1. Стадии совершения преступления: Учеб. пособие / Краснояр. гос. ун-т. Красноярск, 1993.

\footnotetext{
14 Уголовное уложение: Объяснение к проекту редакционной комиссии. СПб., 1895. С. 31-32.

${ }^{15}$ См.: Редин М.П. Учение о стадиях осуществления преступного намерения: новая парадигма в мировой уголовно-правовой науке [Электронный ресурс] // Режим доступа: http://sartraccc.sgap.ru/i. php?oper=read_file\&filename=Pub/redin(05-07-09). htm.; Он же. Учение о стадиях осуществления преступного намерения: новая парадигма в мировой уголовно-правовой науке // Современное право. 2009. № 10. С. 127-130.
} 


\section{Право и политика 3 (159) 2013}

4. Кони А.Ф. О праве необходимой обороны. М., 1996.

5. Кузнецова Н.Ф. Ответственность за приготовление к преступлению и покушение на преступление по советскому уголовному праву. М., 1958.

6. Советское уголовное право. Общая часть: Учебник / Под ред. Г.А. Кригера, Н.Ф. Кузнецовой, Ю.М. Ткачевского. 2-е изд., доп. и перераб. М., 1988.

7. Уголовное право. Общая часть / Под ред. Н.Ф. Кузнецовой и др. М., 1993.

8. Учебник уголовного права. Общая часть. М., 1996.

9. Редин М.П. Понятия оконченного и неоконченного преступлений в уголовном законодательстве Российской Федерации // Правоведение. 1997. № 1.

10. Редин М.П. Осуществление преступного намерения и неоконченное преступление // Вестник Саратовской государственной академии права. 1998. № 2.

11. Редин М.П. Осуществление преступного намерения и неоконченное преступление // Правоведение. 1999. № 1.

12. Редин М.П. Преступления по степени их завершённости. Монография. - М.: Издательство «Юрлитинформ», 2006.

13. Редин М.П. О состоянии и перспективах использования в уголовном законотворчестве и правоприменении учения о стадиях осуществления преступного намерения // Изменение преступности и актуальные вопросы законодательства по борьбе с ней / Материалы Междунар. науч.-практ. конф., состоявшейся в Тамбовском филиале Московского университета МВД России, 23-24 июня 2005 г. - Тамбов: Тамбовский филиал МосУ МВД России, 2005.

14. Редин М.П. Учение о стадиях осуществления преступного намерения: его сущность, использование в законотворчестве и правоприменении // Материалы I Всероссийского конгресса по уголовному праву, посвященного 10-летию Уголовного кодекса Российской Федерации. М., 2006.

15. Редин М.П. О методологии и методах научного познания преступлений, совершаемых с прямым умыслом // Юридическая мысль (г. Санкт-Петербург). 2006. № 6.

16. Редин М.П. Еще раз об учении о стадиях осуществления преступного намерения // Современное право. 2007. № 5.

17. Редин М.П. О конструкции составов преступлений, предусмотренных статьями 277, 295, 317 УК РФ // Следователь. 1999. № 2.

18. Редин М.П. Еще раз о конструкции составов преступлений, предусмотренных статьями 277, 295, 317 УК РФ // Современное право. 2007. № 8.

19. Редин М.П. О понятии посягательства на жизнь и конструкции составов преступлений, предусмотренных статьями 277, 295, 317 Уголовного кодекса Российской Федерации // Безопасность бизнеса. 2007. № 3.
20. Редин М.П. О квалификации бандитизма и преступных деяний, совершенных бандой // Современная организованная преступность и коррупция в России: состояние, тенденции, проблемы и возможности эффективного противодействия: тезисы Международной научно-практической конференции (27-28 февраля 2007 года, г. Саратов): в 2 ч. / отв. ред. А.И. Демидов. Саратов: Изд-во ГОУ ВПО «Саратовская государственная академия права», 2007. Ч. 1.

21. Редин М.П. Разбой (понятие, конструкция состава) // Современное право. 2007. № 10.

22. Редин М.П. О понятии убийства в российском уголовном законодательстве // Российская юстиция. 2007. № 10.

23. Редин М.П. Об ограничении законодательной регламентации смертной казни // Уголовное право: стратегия развития в XXI веке: материалы Пятой Международной научно-практической конференции 24-25 января 2008 г. - М., 2008.

24. Редин М.П. О конструкции состава необходимой обороны (статья 37 Уголовного кодекса РФ) // Современное право. 2006. № 2.

25. Редин М.П. О противоречиях в наименовании ст. 30 и в формулировках ч. 2 ст. 29, ч. 1-3 ст. 30, ч. 1 ст. 31 Уголовного кодекса РФ [Электронный ресурс] // Журнал «Российское право в Интернете. Номер 2009 (05) Спецвыпуск / Режим доступа: http://www.rpi.msal. ru/prints/200905_41redin.html.

26. Редин М.П. Учение о стадиях осуществления преступного намерения: новая парадигма в мировой уголовно-правовой науке [Электронный ресурс] // Режим доступа: http://sartraccc.sgap.ru/i.php?oper=read file\&filename $=$ Pub/redin(05-07-09). htm

27. Редин М.П. Учение о стадиях осуществления преступного намерения: новая парадигма в мировой уголовно-правовой науке // Современное право. 2009. № 10.

28. Редин М.П. О соотношении стадий осуществления преступного намерения и видов преступлений по степени их завершенности, добровольного отказа от доведения до конца деятельности по реализации преступления [Электронный ресурс] // Режим доступа: http:// sartraccc.sgap.ru/i.php?oper $=$ read_file\&filename $=\mathrm{Pub} /$ redin(02-10-08). htm;

29. Редин М.П. О соотношении стадий осуществления преступного намерения и видов преступлений по степени их завершенности // Вестник Орловского государственного университета. Серия: «Новые гуманитарные исследования». 2008. № 4.

30. Уголовное уложение: Объяснение к проекту редакционной комиссии. СПб., 1895.

31. Яни П.С. О личности учёного // Весь мир живёт до тех пор, пока живёт память человека / Под общей редакцией профессора В.С. Комиссарова. М., 2006. 


\section{References (transliteration):}

1. Durmanov N.D. Stadii soversheniya prestupleniya po sovetskomu ugolovnomu pravu. M., 1955.

2. Kozlov A.P. Neokonchennoe prestuplenie: Ucheb. Posobie / Krasnoyar. gos. un-t. Krasnoyarsk, 1999.

3. Kozlov A.P. Stadii i neokonchennoe prestuplenie. Vyp. 1. Stadii soversheniya prestupleniya: Ucheb. posobie / Krasnoyar. gos. un-t. Krasnoyarsk, 1993.

4. Koni A.F. O prave neobkhodimoy oborony. M., 1996.

5. Kuznetsova N.F. Otvetstvennost' za prigotovlenie k prestupleniyu i pokushenie na prestuplenie po sovetskomu ugolovnomu pravu. M., 1958.

6. S G.A. Kriger, N.F. Kuznetsova, Yu.M. TkachevskH Sovetskoe ugolovnoe pravo. Obshchaya chast': Uchebnik / Pod red. G.A. Krigera, N.F. Kuznetsovoy, Yu.M. Tkachevskogo. 2-e izd., dop. i pererab. M., 1988.

7. N.F. Kuznetsova Ugolovnoe pravo. Obshchaya chast' / Pod red. i dr. M., 1993.

8. Redin M.P. Ponyatiya okonchennogo i neokonchennogo prestupleniy v ugolovnom zakonodatel'stve Rossiyskoy Federatsii // Pravovedenie. 1997. № 1.

9. Redin M.P. Osushchestvlenie prestupnogo namereniya i neokonchennoe prestuplenie // Vestnik Saratovskoy gosudarstvennoy akademii prava. 1998. № 2 .

10. Redin M.P. Osushchestvlenie prestupnogo namereniya i neokonchennoe prestuplenie // Pravovedenie. 1999. № 1.

11. Redin M.P. Prestupleniya po stepeni ikh zavershennosti. Monografiya. - M.: Izdatel'stvo «Yurlitinform», 2006.

12. Redin M.P. O sostoyanii i perspektivakh ispol'zovaniya $\mathrm{v}$ ugolovnom zakonotvorchestve i pravoprimenenii ucheniya o stadiyakh osushchestvleniya prestupnogo namereniya // Izmenenie prestupnosti i aktual'nye voprosy zakonodatel'stva po bor'be s ney / Materialy Mezhdunar. nauch.-prakt. konf., sostoyavsheysya v Tambovskom filiale Moskovskogo universiteta MVD Rossii, 23-24 iyunya 2005 g. - Tambov: Tambovskiy filial MosU MVD Rossii, 2005.

13. Redin M.P. Uchenie o stadiyakh osushchestvleniya prestupnogo namereniya: ego sushchnost', ispol'zovanie v zakonotvorchestve i pravoprimenenii // Materialy I Vserossiyskogo kongressa po ugolovnomu pravu, posvyashchennogo 10-letiyu Ugolovnogo kodeksa Rossiyskoy Federatsii. M., 2006.

14. Redin M.P. O metodologii i metodakh nauchnogo poznaniya prestupleniy, sovershaemykh s pryamym umyslom // Yuridicheskaya mysl' (g. Sankt-Peterburg). 2006. № 6.

15. Redin M.P. Eshche raz ob uchenii o stadiyakh osushchestvleniya prestupnogo namereniya // Sovremennoe pravo. 2007. № 5 .

16. Redin M.P.Okonstruktsii sostavov prestupleniy, predusmotrennykh stat'yami 277, 295, 317 UK RF // Sledovatel'. 1999. № 2.

17. Redin M.P. Eshche raz o konstruktsii sostavov prestupleniy, predusmotrennykh stat'yami 277, 295, 317 UK RF // Sovremennoe pravo. 2007. № 8.
18. Redin M.P. O ponyatii posyagatel'stva na zhizn' $i$ konstruktsii sostavov prestupleniy, predusmotrennykh stat'yami 277, 295, 317 Ugolovnogo kodeksa Rossiyskoy Federatsii // Bezopasnost' biznesa. 2007. № 3.

19. Redin M.P. O kvalifikatsii banditizma i prestupnykh deyaniy, sovershennykh bandoy // Sovremennaya organizovannaya prestupnost' i korruptsiya v Rossii: sostoyanie, tendentsii, problemy i vozmozhnosti effektivnogo protivodeystviya: tezisy Mezhdunarodnoy nauchnoprakticheskoy konferentsii (27-28 fevralya 2007 goda, g. Saratov): v 2 ch. / otv. red. A.I. Demidov. Saratov: Izd-vo GOU VPO «Saratovskaya gosudarstvennaya akademiya prava», 2007. Ch. 1.

20. Redin M.P. Razboy (ponyatie, konstruktsiya sostava) // Sovremennoe pravo. 2007. № 10.

21. Redin M.P. O ponyatii ubiystva v rossiyskom ugolovnom zakonodatel'stve // Rossiyskaya yustitsiya. 2007. № 10.

22. Redin M.P. Ob ogranichenii zakonodatel'noy reglamentatsii smertnoy kazni // Ugolovnoe pravo: strategiya razvitiya v XXI veke: materialy Pyatoy Mezhdunarodnoy nauchno-prakticheskoy konferentsii 24-25 yanvarya 2008 g. - M., 2008.

23. Redin M.P. O konstruktsii sostava neobkhodimoy oborony (stat'ya 37 Ugolovnogo kodeksa RF) // Sovremennoe pravo. 2006. № 2 .

24. Redin M.P. O protivorechiyakh $\mathrm{v}$ naimenovanii st. 30 i v formulirovkakh ch. 2 st. 29 , ch. $1-3$ st. 30 , ch. 1 st. 31 Ugolovnogo kodeksa RF [Elektronnyy resurs] // Zhurnal «Rossiyskoe pravo v Internete. Nomer 2009 (05) Spetsvypusk / Rezhim dostupa: http://www.rpi.msal.ru/ prints/200905_41redin.html.

25. Redin M.P. Uchenie o stadiyakh osushchestvleniya prestupnogo namereniya: novaya paradigma $\mathrm{v}$ mirovoy ugolovno-pravovoy nauke [Elektronnyy resurs] // Rezhim dostupa: http://sartraccc.sgap.ru/i.php?oper=read file\&filename $=$ Pub/redin(05-07-09). htm

26. Redin M.P. Uchenie o stadiyakh osushchestvleniya prestupnogo namereniya: novaya paradigma v mirovoy ugolovno-pravovoy nauke // Sovremennoe pravo. 2009. № 10.

27. Redin M.P. O sootnoshenii stadiy osushchestvleniya prestupnogo namereniya i vidov prestupleniy po stepeni ikh zavershennosti, dobrovol'nogo otkaza ot dovedeniya do kontsa deyatel'nosti po realizatsii prestupleniya [Elektronnyy resurs] // Rezhim dostupa: http://sartraccc.sgap.ru/i.php?oper $=$ read_file\&filename $=\mathrm{Pub} /$ redin(02-10-08). htm;

28. Redin M.P. O sootnoshenii stadiy osushchestvleniya prestupnogo namereniya i vidov prestupleniy po stepeni ikh zavershennosti // Vestnik Orlovskogo gosudarstvennogo universiteta. Seriya: «Novye gumanitarnye issledovaniya». 2008. № 4.

29. Yani P.S. O lichnosti uchenogo // Ves' mir zhivet do tekh por, poka zhivet pamyat' cheloveka / Pod obshchey redaktsiey professora V.S. Komissarova. M., 2006. 